\title{
The Via Francigena del Sud: The value of pilgrimage routes in the development of inland areas. The state of the art of two emblematic cases
}

\author{
Anna Trono*a / Valentina Castronuovo ${ }^{b}$ \\ a University of the Salento, Dipartimento di Beni Culturali, Edificio ex INAPLI, Via Dalmazio Birago 64, 73100 Lecce (LE), Italy \\ b National Research Councel (CNR), Institute for Research on Innovation and Services for Development (IRIS), Via Guglielmo \\ Sanfelice 8, 80134 Naples, Italy
}

Received: 10 May 2021 / Accepted: 30 July 2021

\begin{abstract}
On October 18 1 th 2019 , the European Vie Francigene Association (AEVF) unanimously approved the Via Francigena in southern Italy, from Rome to Santa Maria di Leuca. The new route enriches the historical cultural itinerary approved by the Council of Europe in 1994. Encompassing about $900 \mathrm{~km}$ of history, traditions and locations, the "Via Francigena del Sud" crosses five Italian regions. This paper focuses on the Via Francigena in Puglia and Campania, seen as an opportunity to conserve and enhance the regions' cultural and landscape heritage and its enjoyment by tourists. Furthermore, it also aims to analyse the role of local businesses, communities and regional organisations in promoting the routes. Any project focusing on the development and enhancement of a cultural itinerary in a rural space must be fully aware of the connections between places and networks of human relationships, and the "Via Francigena del Sud" seems to be no exception.
\end{abstract}

\section{Keywords}

Via Francigena del Sud; Puglia Region; Campania Region; pilgrimage route; local government.

\section{A Vía Francíxena do Sur: o valor das rutas de peregrinaxe no desenvolvemento das zonas do interior. 0 estado da arte de dous casos emblemáticos}

\section{Resumo}

O 18 de outubro de 2019, a Asociación Europea Vía Francíxena (AEVF) aprobou por unanimidade a Vía Francíxena no sur de Italia, desde Roma ata Santa María di Leuca. A nova ruta enriquece o itinerario histórico cultural aprobado polo Consello de Europa en 1994. Abarcando preto de 900km de historia, tradicións e lugares, a "Vía Francíxena do Sur" atravesa cinco rexións italianas. Este documento céntrase na Vía Francíxena en Puglia e Campania, vista como unha oportunidade para conservar e mellorar o patrimonio cultural e paisaxístico das rexións e o seu gozo por parte dos turistas. Ademais, tamén ten como obxectivo analizar o papel das empresas locais, das comunidades e das organizacións rexionais na promoción das rutas. Calquera proxecto centrado no desenvolvemento e posta en valor dun itinerario cultural nun espazo rural debe ser plenamente consciente das conexións entre lugares e das redes de relacións humanas, e "Vía Francíxena do Sur" parece non ser unha excepción.

\section{Palabras clave}

Vía Francíxena do Sur; Rexión de Puglia; Rexión de Campania; ruta de peregrinaxe; goberno local.

JEL Codes: H76, L83, Z32.

\footnotetext{
* A Trono: anna.trono@unisalento.it (corresponding author), V. Castronuovo: v.castronuovo@iriss.cnr.it
} 


\section{Introduction}

Cultural routes and itineraries have recently acquired great importance as tourist destinations and as the expression of a qualitative change in the approach to the protection and conservation of cultural and landscape heritage, now seen as providing opportunities for sustainable regional development.

However, the idyllic relationship between the wayfarer and the community and region being visited requires a shared commitment to building and embellishing the itinerary, which also strengthens the bonds of loyalty with the tourist-pilgrim (Buratti \& Ferrari, 2011). For an optimal management of the routes it is important, to find a way to balance the needs of the residents with those of the visitors, considering what an area must and can do. It is also important to make the route creative and exciting, involving all the senses of the visitors and establishing a personal relationship between the local community and the wayfarers/tourists. Special attention needs to be paid to the quality and authenticity of the route's theme, local culture and traditions, as it is this above all that adds real value to the route and ensures the safeguard, protection and long-term preservation of its cultural heritage.

In order to be effectively operational, however, cultural routes and itineraries require a modernisation of theoretical principles and administrative protocols. What is especially needed is the involvement of national and local governments, which must involve the local community in accordance with a logic of good regional governance. To this end, cooperation between institutions and the establishment of a network of local players are essential steps towards meeting the needs of tourists.

The importance of involving stakeholders in initiatives aimed at sustainable tourism is being recognised and recommended with growing frequency in both the academic world and in-the-field experiences, as shown by the exemplary cases of networks and partnerships, despite a few cases of failure and evident scepticism concerning the ability of some stakeholders to contribute significantly to tourism development processes (Mansfeld, 2015; Waligo, Clarke \& Hawkins, 2015).

The focus on involving local stakeholders is strongly supported by the European Commission, which, with reference to the principles of the United Nations Educational, Scientific and Cultural Organization (UNESCO) and the Council of Europe (Briedenhann \& Wickens, 2004; KhovanovaRubicondo, 2011, 2012), has declared cultural itineraries to be an expression of cultural values and exchange between peoples linked by a common history and heritage. The commission also underlined their advantages in terms of boosting innovation, competitiveness and economic development, especially among medium-sized enterprises, as well as favouring the creation of a network of local authorities and stakeholders (Khovanova-Rubicondo, 2015). This approach has been adopted by governments in many countries including Italy, which has launched numerous initiatives and passed legislation to promote cultural routes for tourism purposes. Moreover, with reference to the Strategic Plan for Tourism 2017-2022, the Ministry of Cultural Heritage and Tourism (MiBACT) proclaimed 2016 the Year of the Routes, with the intention of promoting the rich heritage associated with the network of Routes that cross the country from north to south. The "Cammini e Percorsi" project, included in the Piano Straordinario della Mobilità turistica (Extraordinary Plan for Tourist Mobility) 2017-20221, also uses an integrated transport and tourism model to promote the country's image and cultural and landscape heritage ${ }^{2}$. In this context, it has facilitated the creation of a slow mobility network by creating the Atlante dei Cammini (Atlas of Paths) and a web portal

1 Ministero della Cultura. 2018. Cammini d'Italia. Percorsi tra storia, cultura e paesaggi. Franceschini lancia il portale dei cammini: uno strumento per viaggiatori e turisti: https://www.beniculturali.it/comunicato/cammini-d-italia-percorsi-trastoria-cultura-e-paesaggi-franceschini-lancia-il-portale-dei-cammini-uno-strumento-per-viaggiatori-e-turisti

2 Law 296 of 27 December 2006 article 1 comma 1228, modified by Law 69 of 18 June 2009 (Disposizioni per lo sviluppo economico, la competitività nonché in materia di processo civile), article 18 "Progetti di eccellenza per il rilancio della competitività turistica italiana". More recently, in December 2015, as part of the initiatives to foster regional development and promote entrepreneurship in the tourism sector, a memorandum of understanding was signed by MiBACT, Ministry for Infrastructure and Transport (MIT), National Autonomous Roads Corporation (ANAS S.p.A.) and Agenzia del Demanio for the launch of a project to make use of publicly owned assets, whether property of the state or other bodies, situated along ways and routes of a historical or religious nature that are also suitable for cycling and walking. The project is linked to the theme of "slow" tourism, discovering regions by moving through them at a sedate pace, focusing on lesser-known destinations (Dossier Cammini e percorsi 2018. Cammini e Percorsi, https://consistanbul.esteri.it). 
(www.camminiditalia.it), which together have enabled the first official mapping of Italy's cultural, religious, spiritual and nature-based routes. They also provide an overview of routes that cross littleknown parts of the country, representing an excellent opportunity for the management and organisation of "slow" tourism in the Italian market. The central government and the regional, municipal and local authorities are committed to maximising the value of all 6,600 kilometres of routes, by facilitating the integration of the environment and landscape with agricultural, craft, cultural and tourism activities, as set out in the 2017-2022 Strategic Tourism Plan. Public and private players have welcomed the ministry's "Cammini" initiative, which tasks the Regions with drawing up strategies for specific types of cultural itinerary. This will make it possible to bring together, particularly in rural, inland and peripheral areas, resources of apparently little value for tourism which are nonetheless repositories of historical, cultural, landscape and gastronomic assets, thus enabling the development of new and sustainable models of management and use.

This paper examines the recently established Via Francigena del Sud (VFS) and its ability to strengthen transregional dialogue and interaction. It provides a brief historical account of the process that led to its recognition, and analyses the aims and problems it has faced during its creation and implementation in the socio-economic and cultural contexts of reference. It describes the measures adopted by the Italian Government and the way in which the route of the Via Francigena is perceived and managed by two regions in Southern Italy -Puglia and Campania- focusing on the needs and interpretation of the project by the local stakeholders and public bodies involved. It identifies exemplary elements and potential threats, as well as the impact that the itinerary has or could have in terms of tourism, with reference to the wider potential for the local community, if associated with the creation of networks of operators that can promote the route.

\subsection{Research objectives and methodology}

This paper considers the recently established route of the Via Francigena del Sud and its capacity to promote trans-regional dialogue and interaction. The main objective of this research is to identify and assess the existence of conditions that justify the investment of resources by institutions and local stakeholders in the preservation and appropriate exploitation of the itinerary. Where possible, it also seeks to indicate potential measures that might generate multilevel benefits. In addition to deepening our knowledge of a tourism product linked to territorial heritage, the pursuit of this objective makes it possible to formulate useful content for the tourism-oriented regional planning of marginal areas affected by the Route. After briefly outlining the historical process that led to the recognition of the Via Francigena del Sud, the paper analyses its aims and the problems it faced during its creation and its implementation in the social, economic and cultural contexts of reference. Furthermore, it sets out the policies adopted by the Italian Government and how the Francigena route is viewed and managed by two different regions in Southern Italy -Puglia and Campania- focusing on the needs and the interpretation of the planning implications by the local stakeholders and public bodies involved. The interest in the latter is based on their importance in the participatory development of the itinerary in accordance with shared planning criteria. By means of desk analysis and the consultation of both primary and secondary sources, the research also identifies exemplary cases and threats as well as looking at the inputs that the itinerary either does produce or could produce in terms of tourism, stimulating the growth of specific forms (e.g. ecotourism, slow tourism, green tourism, wine and food tourism) and encouraging the development of enterprises in marginal and depopulated areas. Such tourism potential has wider implications for the local community if it is associated with the creation of networks of operators that can promote the itinerary. This theme is addressed by rich literature (see, among others, Bambi \& Barbari, 2015; Beltramo, 2013; Berti, 2012, 2013; Briedenhann \& Wickens, 2004; Canova, 2012; Dallen, 2018; Dominioni, 2018; Graf \& Popesku, 2016; Majdoub, 2010; Nagy, 2012; Ochoa Siguencia, Gómez-Ullate \& Kamara, 2016; Splendiani, Forlani, Picciotti \& Presenza, 2020; Zabbini, 2012;) which is cited in this paper with specific reference to the case studies. The empirical analysis is also supported by the direct observation of the itinerary's users by means of quantitative- 
qualitative interviews conducted with a random sample of walkers, who were asked to indicate the Route's strengths and weaknesses. Considering the recent recognition of the VFS by the Council of Europe, the absence of detailed monitoring of the walkers ${ }^{3}$ and the meagreness of the sample selected from among travellers passing through a limited portion of the Route in Puglia (about 60 units, including men and women, Italians and foreigners, in 2020), the survey's results must be considered partial and not exhaustive.

\section{The "Via Francigena del Sud" then and now. Objectives, projects and activities for the regeneration of inland areas.}

In October 2019 the European Vie Francigene Association unanimously approved the Via Francigena del Sud, the new route from Rome to Santa Maria di Leuca in Puglia.

The approval of the route (Figure 1), joining about $900 \mathrm{~km}$ of history, tradition and regional assets, is the fruit of an endeavour that began officially in March 2014, but many scholars had already been working on the idea, with tenacity and steadfastness, since the 2000 s.

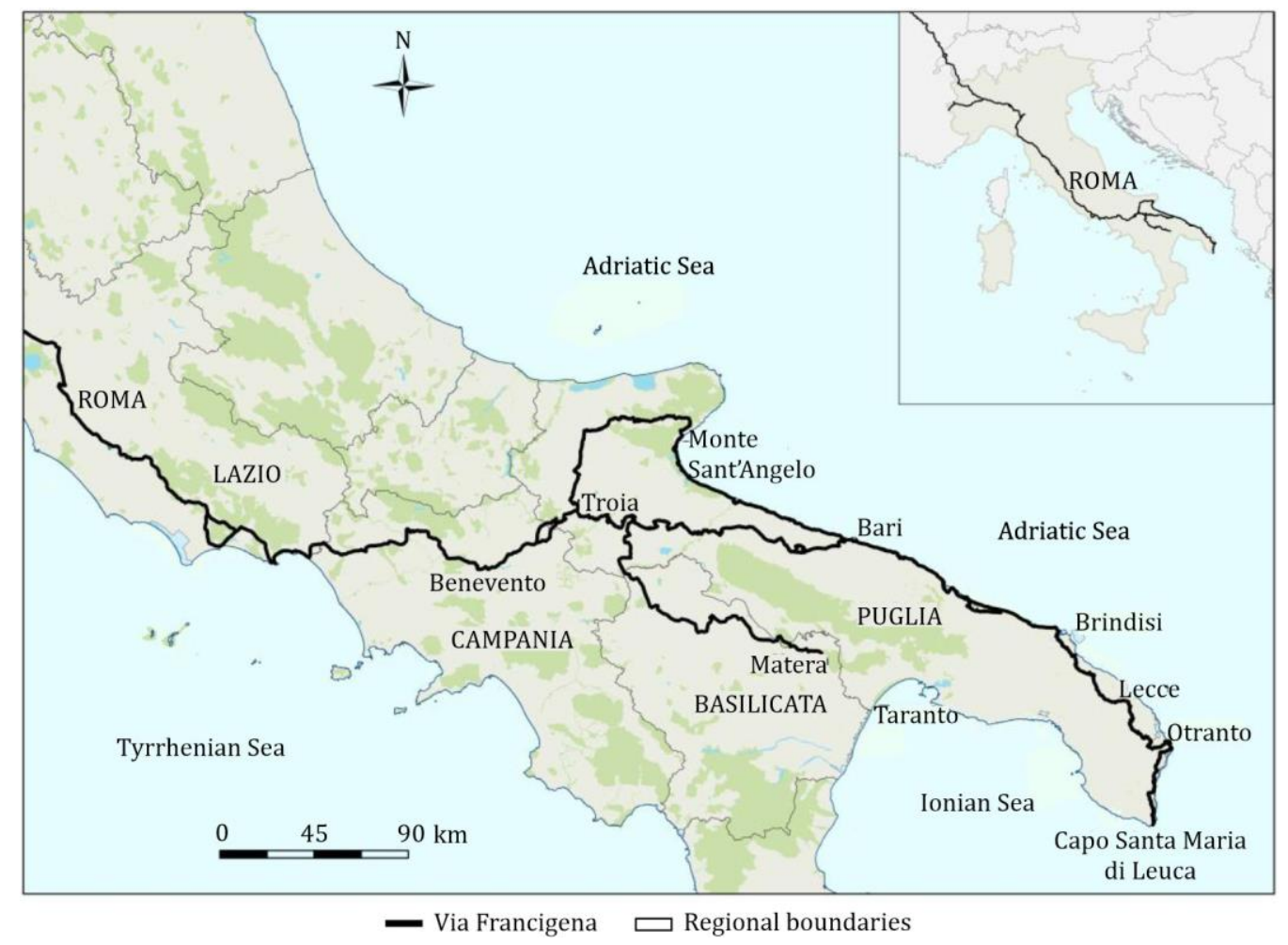

Figure 1. The Via Francigena del Sud. Source: https://www.viefrancigene.org/it/ our presentation.

It was made possible by the broad-based efforts of the AEVF -in consultation with the Italian Ministry of Culture and the European Institute of Cultural Routes- and the Regional administrations of Lazio, Campania, Molise, Basilicata and Puglia, supported by the Italian Geographical Society. Various Italian universities made scientific contributions and associations and private institutions conducted field work. Thus, by means of participatory planning, it was possible to recognise and promote the

3 From the registers of the Sanctuary of Santa Maria di Leuca (Puglia) it is clear that, in 2020, despite the COVID-19 epidemiological emergency, 361 pilgrims arrived on site. 
Itinerary, which metaphorically connects Italy to the countries of the Mediterranean, especially Albania, Macedonia, Greece and Turkey (Società Geografica Italiana, 2015).

Taking account of the current network of paths, the Route follows the Itinerarium Burdingalese of 333 AD (Vanzo, 2021), which has clearly been modified since the late ancient period, partly due to the intense impact of human activities, especially in the second half of the $20^{\text {th }}$ century.

Preconditions for the implementation of the Route include the institution of a technical coordination round table with the Regions, compliance with the criteria required for certification, a review of the wealth of written sources and the adoption of a multidisciplinary approach to the reconstruction of the route (which took account of all the geographical, archaeological, topographical, religious, literary, anthropological and travel-oriented facets). The Route itself constitutes a regional renewal project that establishes a geographical connection between areas of the country characterised in some cases by chronic economic, social and cultural marginalisation.

The role of the Via Francigena del Sud as a type of infrastructure supporting the promotion and development of the regional and national economy was envisaged by CIPE Deliberation 3/2016 (Piano Stralcio "Cultura e Turismo" del Fondo per lo sviluppo e la coesione, scheda intervento n. 33 "Via Francigena"), which allocated 20 million euros to the initiative.

Among the project's general objectives, as well as ensuring the safety and usability of the section of the route from Valle d'Aosta to Lazio, is the intention to trace and georeference a single path, with possible variations, for the section of the route from Rome to Puglia. In addition, the infrastructural and planning measures require the unification into a single system of all the projects and resources already existing and planned by the individual regions affected. This serves to improve the range of cultural and tourism goods and services on offer, support the various forms of hospitality and ensure the accessibility of the landscape of the Route in terms of its environmental complexity and logistics. Thus, from the planning stage, the infrastructure of the Via Francigena del Sud was the key element in an integrated regional operation to ensure the innovativeness and specialisation of the destinations and products via their lasting and sustainable management.

Section 33 ("Via Francigena") of the plan for "Culture and Tourism" of the Italian government's Fund for Development and Cohesion is at the heart of the operational agreement stipulated between all the bodies involved in the process (MiBACT and the relevant Regional Adminstraions) and ratified on 20 December 2019 following approval of the route by the AEVF.

In accordance with the indications of the Council of Europe, the document sets out the planning structures and phases, including the schedule for the implementation of the measures, the indicators for the Route's creation and results, and the system of management and verification -distinguishing between the measures to be performed on the part of the route that has already been decided and the part which is still "under construction", granting regional autonomy on how to achieve the general objectives.

In accordance with the strategic objectives of the agreement, the tasks of the regions involved in the Via Francigena del Sud include a survey on the state of conservation, use and accessibility of the section of the Via Francigena lying within their territory. This concerns infrastructure, the presence of services, and particularly the condition and continuity of the path itself. North and South are both committed to the drafting of the relevant documentation, indicating the technical feasibility of the overall regional plan and the specific measures to be carried out in their respective areas of reference, with each region setting out the order of priority.

According to the Agreement, the works, services and/or supplies shall be completed by 31 December 2022. The joint planning process, which considers the Via Francigena del Sud to be a great opportunity for the development and reorganisation of the places involved, is at the centre of a systemic assessment of the methods of its implementation. The multilevel governance embodied by the bodies tasked with implementing the results of the participatory planning process currently under way can be seen as a "network within a network project". This process of "participation heritage" (Bate, 2011; Butler, 2012; Fairclough, 2011; Graham, 2012) is able to bring out, in ways that are not merely random but are shaped and guided by government policy within the broader context of 
regional regeneration, a new model of cultural heritage, in which the itinerary is both a product (cultural and economic) and a tool for the co-creation of value (Trono \& Castronuovo, 2018).

The Via Francigena del Sud can be seen as a platform of resources, a space in which to establish connections and cooperation, and a context for planning and design (Rispoli, 2001). It is the cultural matrix through which the multifaceted control room recognises the Itinerary as the main element of a shared and attainable future. This premise can facilitate its governance, constituting a set of principles and procedures capable of social, cultural, economic, relational and imaginative transformations.

It is on the basis of these assumptions that the European Vie Francigene Association drew up the planning document for the period 2020-2022 (Associazione Europea delle Vie Francigene, 2020). As part of the seven macro-strategies listed, the Association's main objectives are to increase awareness of European, national and regional public institutions, of the local communities involved, and of the Via Francigena as an engine of local development. The focus is on expanding the capacity of local authorities and the private sector to offer innovative services that can make the most of the Route's distinctive cultural, religious, landscape and historical features at the global level (Associazione Europea delle Vie Francigene, 2020).

To support the macro-strategies, nine operational steps have been identified, prioritised on the basis of their effectiveness, feasibility and visibility. The periodic training offered to associations, communities and private individuals serves to support and expand the project network, with the aim of promoting the Via Francigena's regional governance model at the European level. This is essential for the positioning of the Route in the context of the Council of Europe's Cultural Routes and for its replicability within the emerging system of itineraries. It is also essential to standardise the management of the route in terms of accessibility and sustainability (Associazione Europea delle Vie Francigene, 2020).

In addition, the Via Francigena's management process should take into account the strong economic potential deriving from the offer of services related to the enjoyment of the route and its associated cultural heritage. Adequate planning will thus be needed, assuming a market that is strongly conditioned by the multiple interests and interactions that characterise the groups involved: a market in which the various categories of subjects operate in accordance with an "integrated approach" that reconciles the need for protection and conservation with the needs of management and the socio-economic development of the related regions.

In this framework, protection and use are reconciled in the balanced concept of systemic vitality, which entails the capacity for survival of cultural heritage, understood not only as knowledge of the physical structure of the assets, but also, and above all as the increasingly effective expression of their cultural function in the various contexts subject to intervention (Zabbini, 2012). The measures adopted to enhance the cultural, social and economic value of heritage are therefore a key part of the process. Above all, this is because of the importance of heritage as an expression of the identity of a community and its ability to elaborate its social memory and prefigure its future. However, the measures are also able to involve various bodies and support the development of local economies. Management is therefore expanding beyond its traditional boundaries, both horizontally -from individual assets to the entire area of reference- and vertically -from knowledge to economic exploitation and marketing- while respecting the value of the places involved.

\section{Strategies for the promotion and management of the Via Francigena del Sud.}

The Via Francigena del Sud runs from Rome to Otranto on the eastern edge of the Puglia region. It follows the route of what were once the two most important arteries in southern Italy: the Via Appia from Rome to Benevento and the Via Traiana from Benevento to Brindisi, where it connects to the Via Traiana Calabra which leads to Otranto, the last port of embarkation on the Adriatic coast for pilgrims and crusaders headed to the Holy Land. Following the ancient Via Sallentina, it reaches Santa Maria di Leuca, an important centre of Marian devotion. In Troia, in the Tavoliere plain near Foggia, the VFS 
splits into two routes: one turns north towards Monte Sant'Angelo following the Via Micaelica and the other continues south across Puglia. After crossing the Murgia hills, it runs along the Adriatic coast to the Column of Trajan in Brindisi, passing by the excavations of Egnatia (Figure 2), the Regional Park of the Coastal Dunes between Torre Canne and Torre San Leonardo and the state nature reserve of Torre Guaceto.

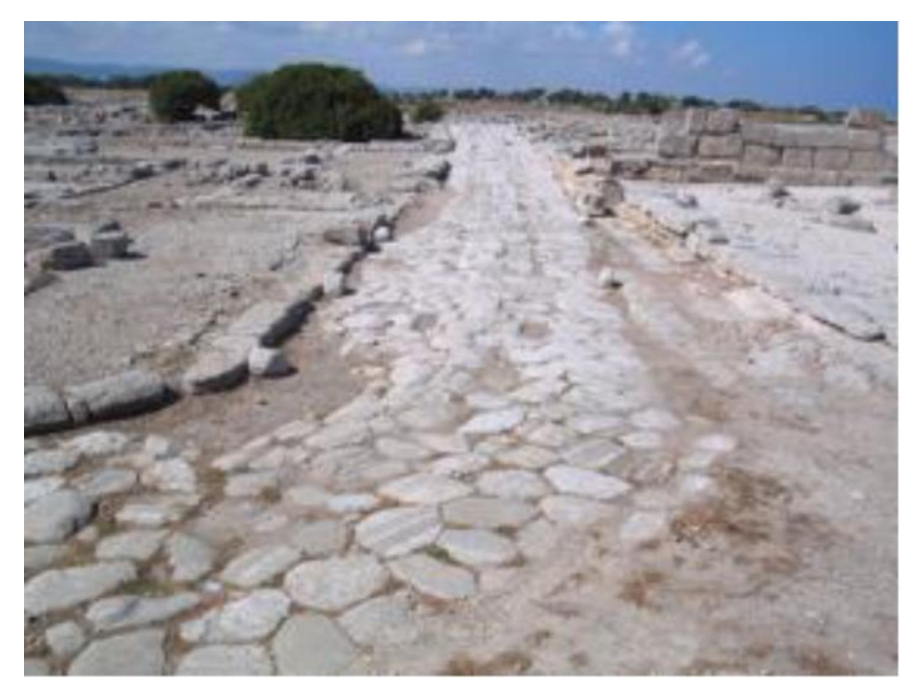

Figure 2. Park of Egnatia. Remains of the ancient Via Traiana. Source: Fabio Mitrotti.

The Via Francigena del Sud, like the northern section, generally follows the medieval route taken by the peoples of northern Europe from the 9th century to the beginning of the modern era to reach Rome and then continue on to the ports of embarkation for the Holy Land. However, it should be borne in mind that the pilgrims' route was often modified for safety reasons, and today it has been adapted to take account of the transformations of the landscape and the urbanisation that have taken place over time, while making sure that it remains passable for walkers.

Together with the complex morphology of the Samnite Apennines and the Daunian Sub-Apennines, with the lower reliefs between the mountainous and hilly areas, the historical events occurring here in the Roman and Medieval periods make the region crossed by the VFS particularly interesting for the modern traveller. The area is characterised by abbeys and sacred buildings, and the ruins of Roman bridges and ancient taverns, perhaps once places of rest and refreshment for travellers and pilgrims. Here, the sense of the sacred, religiosity, pilgrimages and devotional worship have had such a strong impact on local communities over time that they have become an indisputable marker of regional identity. The VFS crosses urban areas, but also areas that have been less affected by human activities, with small municipalities, areas of exceptional importance for nature, outstanding rural environments and historical, artistic, cultural and religious heritage of great value. There are also distinctive economic activities, especially crafts, which have great potential in terms of tourism. Attracting contemporary pilgrims, they are of interest to administrators and those operating in the tourism sector.

The VFS is therefore both a tool for consolidating local identity and an opportunity to promote local products, both agricultural/gastronomic and small-scale industrial/craft. It thus helps to define local and regional branding as part of a complex process that is becoming increasingly important for attracting experiential tourism and empowering local entrepreneurs and producers.

In order to optimise these results, the VFS has been enriched by the regional authorities with numerous "variants" with respect to the original historical route, such as the one that skirts the city of 
Matera or that of Molise, as well as the many others of a devotional nature recognised by Puglia Regional Administration (Figure 3).

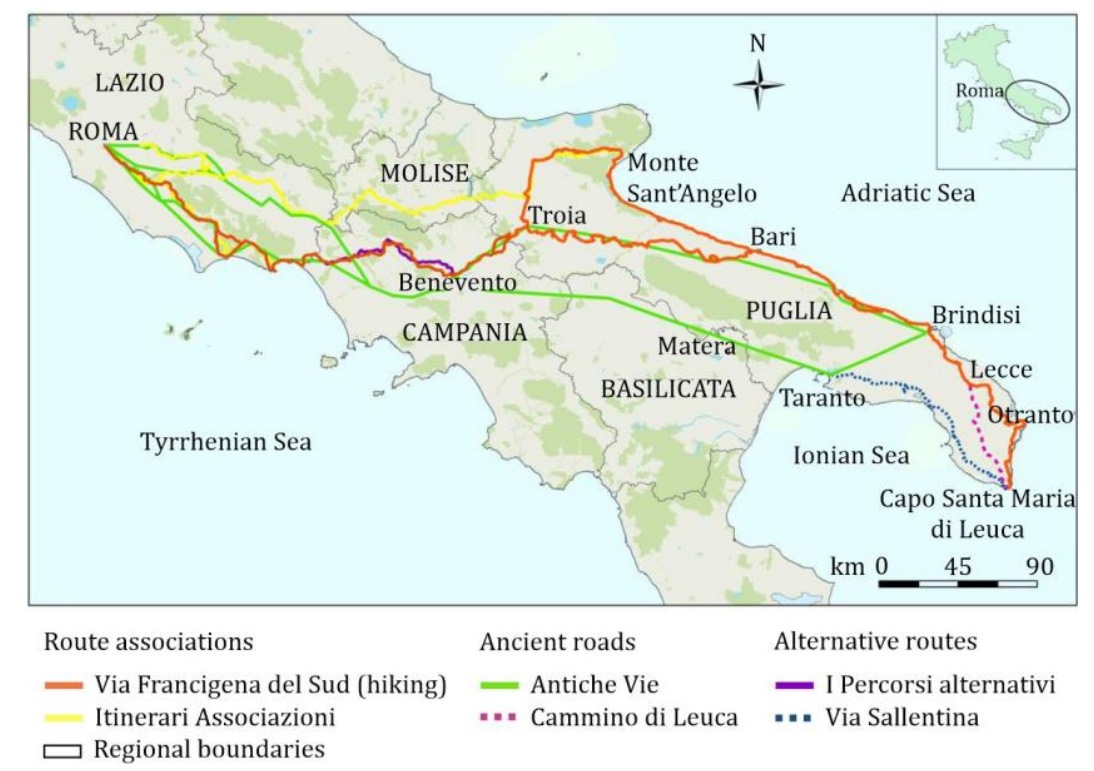

Figure 3. The Via Francigena del Sud and the regional "variants". Source: https://www.viefrancigenedelsud.it/it/ and https://www.viaggiareinpuglia.it/2018/pdf/Guida-cammini-web\%202801_ok.pdf. Our presentation.

These are political responses that are partly aimed at promoting inland and rural areas, but they also seek to remedy an undeniable limitation of the route. Indeed, until arrangements have been made for its continuation towards Jerusalem and the Holy Land, the route goes no further than the ancient pilgrims' ports of embarkation. These cities are undeniably endowed with scenic, cultural and historical qualities, but they do not represent the important final destination of the European Via Francigena (Trono, 2012, 2017; Trono, Ruppi, Mitrotti \& Cortese, 2017).

There is a clear need therefore to draw the interest of the traveller more to the journey than to the final destination (Trono \& Olsen, 2018), shifting attention towards other objectives that align with a series of tendencies currently affecting tourism. These include slow tourism, which emphasises the stages of the journey and the enjoyment of the time spent on it; spiritual tourism (or tourism of the soul); and experiential tourism, given that the route transforms the act of travelling into a meaningful experience.

As emerges from the sample of pilgrims interviewed in the section of the route passing through the municipalities of Torchiarolo (Brindisi) and Cannole (Lecce), who were asked questions on (i) their reasons for choosing the route and the value of the experience, (ii) the presence of infrastructure and services and (iii) their degree of satisfaction compared with other experiences of Cultural Routes that they may have had. Today, those who walk the VFS route are interested above all in more dynamic and participatory forms of knowledge of a region's history and identity. Their perception is filtered by their sensitivity, culture and motivation. The fulfilment of their expectations for the trip -spiritual, cultural and recreational- as well as the welcome offered by the local communities, frames the user of the VFS as the protagonist of a new approach to leisure travel: a participant, attentive both to quality and to the cultural and environmental assets of the regions being visited. Such a traveller seeks an experience: they are eager to learn about the "other", to discover new places, towns, churches, traditions, handicraft, food-and-wine, and thus to establish a new, more authentic and direct relationship with the local culture. 
In addition however, the interviews revealed a series of problems, such as the inadequate signage, issues with the care and maintenance of the route, the lack of hospitality services at reasonable prices and the absence of points of reference at each stage, which are an important support for the wayfarer. Despite the limited size of the sample, it is possible to see how the results of a tool based on the direct questioning of the user is particularly useful for the creation of robust and effective infrastructure along the route (González, Sánchez \& López 2014; Martínez, Novello \& Murias 2009;).

Exploiting the full potential of the VFS therefore means focusing on the new way of travelling, aimed at understanding and appreciating local heritage, especially that of "slow territories", where "slowness becomes a distinctive factor of development" (Rizzi, 2011, p. XI) and it is possible to explore the sedimentation of history with reference to the signs of human activity. The VFS is an opportunity to enhance the value of "minor regions", far away from the centre and affected by depopulation, but not backward or depressed. Indeed, they typically have a high quality of life and offer tourism that is compatible and accessible to all. However, they are often fragile and therefore easily disrupted, requiring management strategies that minimise uncertainty but also require a high degree of responsibility in ensuring the protection, preservation and sustainability of the area. In such places it is possible to practise 'soft' tourism integrated with slow mobility, with a preference for ecotourismoriented routes that focus on characteristic local products, which represent an essential component of the attractiveness and competitiveness of the areas concerned. The results, in terms of effectiveness and efficiency, are closely dependent on the interpretative and managerial capacity of local governance.

\subsection{Public and private activities to activate the Via Francigena del Sud in the Puglia region}

The strategy adopted in Puglia for the promotion and management of the Via Francigena is seen in the creation of a network of public bodies and private citizens.

Puglia Regional Administration considers the stakeholders to be beneficiaries of a range of initiatives and the means by which to ensure the success of the venture. It therefore deliberately includes them in its strategy for promoting the Route by involving them in the management process. The Administration thus seeks to identify the stakeholders, establish what they want and determine how this can be achieved.

The Regional Administration's engagement with stakeholders unfolds via public tenders involving LAGs, individual municipalities, cultural associations and individual citizens. This means that local businesses, inhabitants, associations and local and regional authorities all have a role in drawing up an effective and successful management plan. Specifically, since part of the management is not always entrusted by the state to the private sector, it is hoped that young entrepreneurs will assert their role in this process, demonstrating their ability to think and act constructively, in accordance with the fundamental precepts of sustainability. That said, as a general principle, entrepreneurial activity in relation to cultural landscapes, routes and heritage should demonstrate the ability to invest in the region's assets and resources, ensuring travellers enjoy the cultural dimension of their journey, producing stable social and economic development in the regions they pass through.

The Regional Administration's first line of intervention follows the national plan drawn up by MiBACT, which, as mentioned above, sees the Via Francigena and the vast network of Routes as one of the key sectors for repositioning Italy's extraordinary beauty based on proximity tourism that guarantees slow, widespread, seasonally balanced and high-quality tourism.

The second round of measures by Puglia Regional Administration involves the European Agricultural Fund for Rural Development (EAFRD) under the LEADER programme, the mainstay of the regional rural development plan. The latter operates via local Local Action Group (LAGs), offering citizens the chance to set up businesses and become key players in the provision of services and accommodation and catering facilities. 
Even before the recognition of the VFS, LAGs in both southern Italy (Campania, Abruzzo and Puglia) and northern Italy (Emilia Romagna) had identified the Via Francigena as an opportunity for an interregional cooperation project that could boost rural areas. The "Cammini d'Europa" programme (Rural Development Programme 2007-2013 Axis 4 - Measure 421) targeted rural areas crossed by the two main European historical-religious itineraries (the Camino de Santiago and the Via Francigena). It offered a new opportunity to fulfil the tourism potential of towns and rural areas that were typically excluded from the major international tourism circuits, based on the inherent advantages of cooperation.

Benefiting from the many years of experience of the Cammini d'Europa programme, as part of its Rural Development Plan for the 2014-2020 programming period, Puglia Regional Administration has financed measures to promote the VFS initiated by local LAGs. Among these, the LAG Alto Salento deserves special mention, as it operates in an area of rich natural, landscape, historical and artistic value. In collaboration with the Parco delle Dune Costiere and various interest groups from the public and private sectors and civil society, the GAL Alto Salento has launched a series of measures aimed at strengthening interest in the Via Francigena, focusing on care for and protection of the landscape and slow and conscious tourism. Bringing together nature reserves, historic farms, underground oil mills, ancient olive groves and Byzantine rock-cut churches dating back to the $10^{\text {th }}$ and $11^{\text {th }}$ centuries, it has activated new ways for visitors to experience cultural and social history and immaterial and material heritage. One line of intervention (measure 3.2) finances small accommodation activities that have adapted to provide slow tourism services. Further support (measure 3.1) is targeted at citizens who intend to set up businesses offering tourism services that promote traditional agriculture, high-quality production and the safeguard of the rural landscape. Also worthy of note is the focus on the Via Francigena by the GAL Terra dei Messapi. Within the framework of the Rural Development Programme, it has issued calls for proposals aimed at promoting rural areas. Among these is Measure 1.4, closely related to 1.3 "Aid for start-ups", which provides support for innovation in the market for traditional local products. Measure 2.1 provides incentives for the creation and development of small and medium-sized enterprises (SMEs) linked to innovative tourism in the area crossed by the Via Francigena.

A third opportunity to promote the VFS involves Puglia Regional Administration working in partnership or association with projects financed within the framework of European cooperation programmes that allow the creation of a regional system of routes, helping to define a common identity and a shared plan for quality sustainable tourism.

In this situation, the promotion of the VFS is based on a multi-level intervention strategy involving local communities, associations, public bodies, experts and scholars working together in a climate of dialogue and common growth. It finances the construction of infrastructure (e.g. the vertical and horizontal signposting of the route) and the creation or functional restoration of structures for hospitality services. A case in point is the funding for the former Youth Hostel in Brindisi, as part of the "Brindisi e le Antiche Strade" (Brindisi and the Ancient Roads) project, which is attentive to accessibility and had already been proposed by the Municipality of Brindisi as part of the Thematic Routes and Networks project. The latter is one of the two strategic European projects presented by the AEVF and Puglia Regional Administration and financed under the Interreg V/A Greece-Italy European Cooperation Programme 2014/20204.

4 Designed to develop slow tourism, with a focus on cultural heritage and natural resources, the Thematic Routes and Networks project envisages the safeguard, promotion, repurposing and integrated use of significant built heritage and the development of infrastructure for natural resources, in addition to the creation of a brand to attract new visitors. It aims to promote integration of sectors in cross-border areas via joint management models and a common knowledge platform and to increase the administrative efficiency of beneficiaries in the management of cultural tourism capital. A second strategic project, the Coastal Heritage Network, aims to safeguard and protect the environment and promote resource efficiency; to fulfil the economic potential of the cultural heritage and natural resources within the programme area; and to create an Adriatic-Ionian Coastal itinerary linking important sites hosting historical built heritage in eligible regions of the transnational area. 
As part of the EU's Adrion programme, the Quality Network for Sustainable Tourism - QneST project has recognised the Via Francigena in the Salento peninsula as one of four cultural itineraries designed to boost the economic value of cultural and natural resources in the Adriatic-Ionian area, foster the professional management of cultural itineraries and develop the range of cross-border tourism products and services on offer (Trono, 2021).

Another strand of the Via Francigena del Sud promotion strategy involves a group of key stakeholders: municipal administrations, companies, organisations representing specific sectors, scholars and cultural associations eager to promote the Route as an opportunity for development of economic sectors (agriculture, handicraft, tourism and commerce) that have been affected by the pandemic and other natural catastrophes and structural crises that have impacted the local economy. Their objective is to create a network of interest that will be successful in the medium-to-long term. Together they have built a system rich in emotional, economic and social resources that can transform the Salento stretch of the Via Francigena into a "complex cultural item" that can free the region from $a$ tourism that is essentially beach-oriented, hedonistic, voracious and unsustainable, replacing it with slow, experiential and responsible mobility.

The latter initiatives are the work of cultural clubs and associations such as the Associazione Via Francigena Pugliese (AVFP) and the Associazione Le comunità ospitanti degli itinerari delle vie Francigene della Puglia meridionale. In collaboration with secular and religious bodies, local and national, interested in extending the Via Francigena as far as Otranto and Santa Maria di Leuca, they have set up a project to reconstruct the Puglia section of the route including its sub-regional variants (Appia, Traiana and Sallentina), based on the ancient Roman branches of the Via Appia Traiana. They have studied, geo-referenced and mapped the route, drawing the historical, cultural and natural resources into a single system. In collaboration with other cultural associations in Puglia (Arci Lecce, Fondazione Moschettini, Cantiga della Serena Associazione Cammini di Puglia and Rete Civica per la Tutela del Paesaggio e del Patrimonio Artistico e Archeologico di Puglia), they have set up a committee for the promotion of host communities and the creation of services and structures for wayfarers. Since tracing the route, they have sought to actively involve the municipalities through which it passes, organising cultural events (conferences, festivals, etc.). Their ultimate objective is for the Via Francigena to be recognised as a sign of identity and a tool for promoting regional development.

Other praiseworthy initiatives involving the organisation of conferences have been led by cultural associations such as the Archeoclub of Trani and the Soroptimist Clubs of Lecce and Maglie. Above all there are promotional activities involving economic operators in the agricultural, craft and tourism sectors such as the farmers' association (Confagricoltura) of Lecce, which represents the interests of numerous agritourism establishments and local farms committed to biodiversity, and the craft workers' association (Confartigianato) of Lecce. Also involved is the TEGing Puglia project, involved in the creation of networks of operators and activities to support the correct organisation of the foodand-wine tourism sector in Puglia, providing operators and tourists with selected information and services.

They are all participants in a network project whose purpose is to enhance the services offered and guarantee certain standards that will amplify the work of the individual operators.

Also helping to increase the competitiveness and development opportunities of the rural areas along the Via Francigena del Sud are the initiatives of private individuals wishing to promote the region's assets by means of conferences, musical events and excursions, as well as attempts to remedy the environmental problems along the route. The Citizens' Committees that are being set up at each stage of the route are preparing to welcome travellers, above all by raising the community's awareness of, respect for and protection of the landscape and environment, as well as promoting local food and wine and artistic craftsmanship. Last but not least, thanks to the intelligence and ingenuity of young people, they are generating employment in many sectors.

The Via Francigena is thus understood as a social project in which individual citizens play a leading role, as evidenced by the small town of Cannole (in the province of Lecce) in the eastern Salento, which 
acts as an interface with walkers, offering hospitality and monitoring the flow of pilgrims. It also maintains the route through its territory with respect for environmental sustainability and local cultural characteristics (Figure 4), creating a network of interest among local economic operators.
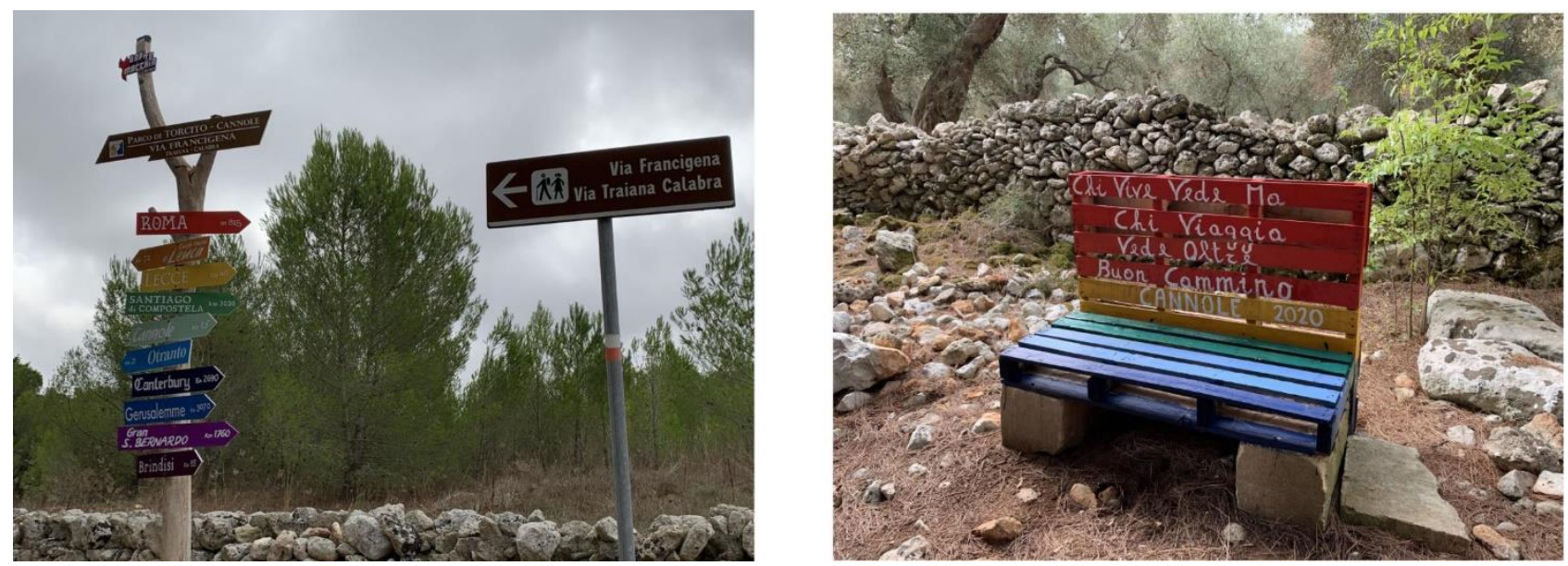

Figure 4. The Via Francigena near Cannole. Source: Anna Trono.

\subsection{Changes and challenges along the routes of the Via Francigena: the case of the Campania region}

In Deliberation 17 of 22/01/2019, Campania Regional Administration approved the route of the main itinerary of the Via Francigena lying within its jurisdiction. In spring 2019, in collaboration with the European Vie Francigene Association (AEVF) and the regional branch of the CAI, the regional section of the route was mapped, georeferenced and analysed by means of a technical feasibility study that provided information on its stages, hospitality sector and cultural heritage, and proposed infrastructural improvements to facilitate use of the itinerary. The Via Francigena in the Campania region has enormous potential, both as a pilgrimage route and as the backbone of a network of "slow" routes. $170 \mathrm{~km}$ long, it passes through 26 municipalities and two provinces (Caserta and Benevento), while a further $200 \mathrm{~km}$ have been identified by the Regional Administration for future cycling and walking variants. The bureaucratic and administrative process began in 2015 with the Regional Administration's Deliberation 886 of 29/12/2015, by which the Region acquired the official maps of the Via Francigena del Sud and set up an interdepartmental workgroup tasked with laying the ground for the validation, implementation and monitoring of the Campania section of the route. Following Deliberation 511 of 27/09/2016, the Regional Administration officially began working with the European Vie Francigene Association and approved the protocol of understanding regarding the "Extension of the Via Francigena del Sud and Certification as a Cultural Itinerary of the Council of Europe". The result of this protocol would be the project's preliminary study, which would subsequently give rise to the official route of the Via Francigena del Sud. In 2017, Campania Regional Administration approved the list of municipalities through which the route ran, as agreed with MiBACT (CIPE Deliberation 3/2016), and the contiguous areas of interest (D.R. 529 of 08/08/2017) (Figure 5), initiating procedures for the improvement of certain stretches such as that of the Valle del Miscano (Ariano Irpino), chronologically the last (2020).

The slow pace of the administrative process in Campania was partly a result of recent developments linked to the Covid-19 pandemic. However, the Regional Administration continued to pursue the specific objectives, deploying transversal measures such as the regional planning strategy for the periods 2007-2013 and 2014-2020 and the Plan for Rural Development, thereby offering 
significant bottom-up opportunities for regional development. Financed by the Rural Development Programme 2007/2013, Axis IV-Measure 421, the EU interregional cooperation project entitled "I Cammini D'Europa: Rete Europea di storia, cultura e turismo" was promoted by 16 LAGs from four Italian Regions. As part of this, the project known as "Il cammino dell'anima" prepared a system of itineraries with a combined length of about $55 \mathrm{~km}$, suitable for walking, cycling and driving, in the north-western part of the Province of Benevento, from Faicchio to Pietrelcina.

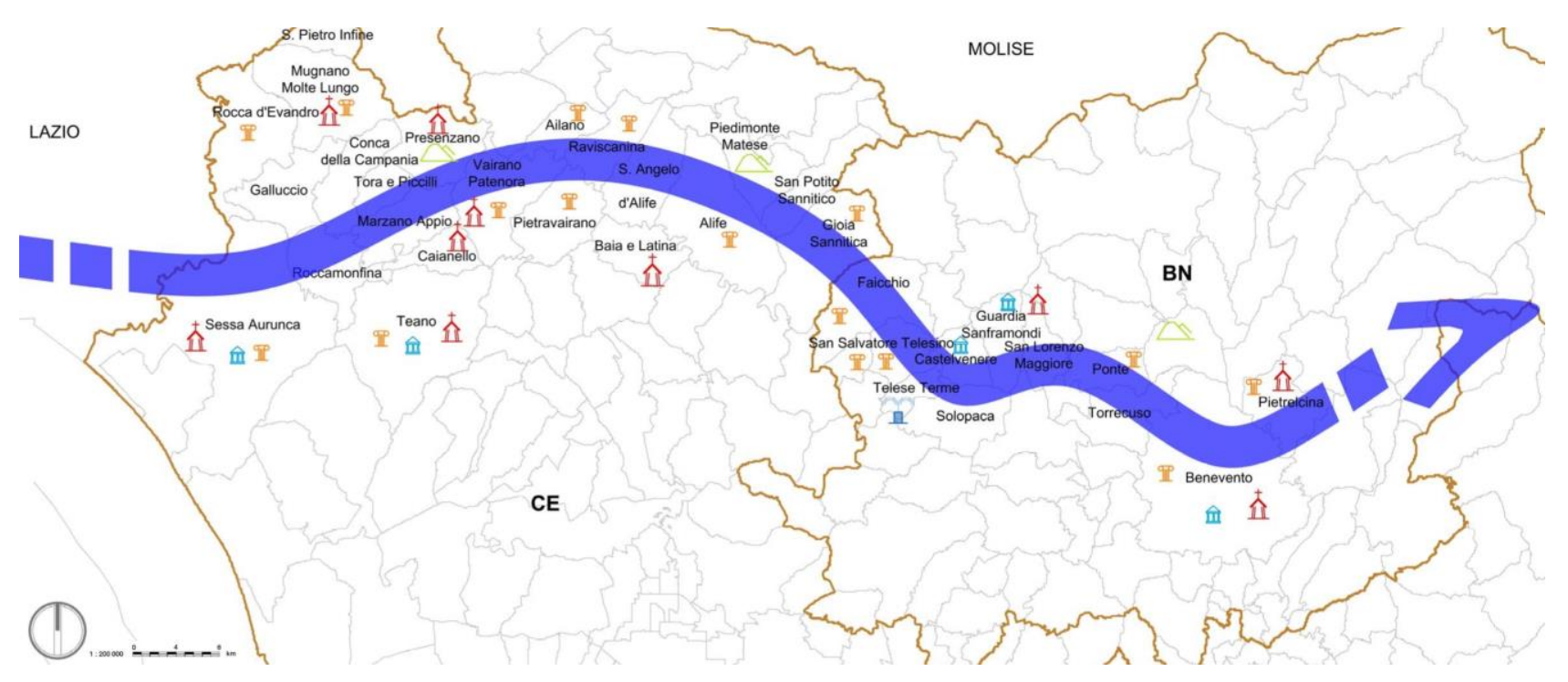

Figure 5. The Via Francigena del Sud in Campania Region. Direction Via Latina-Via Traiana. Source: GAL Titerno.

There are a total of four routes enhancing the "Samnite" section from Faicchio to Benevento, which runs along the course of the river Calore, crossing the entire Telesina Valley. From San Salvatore, with its Benedictine abbey and the remains of ancient Telesia, the route runs through Telese Terme, the flat area of Castelvenere, Guardia Sanframondi, San Lorenzo Maggiore and the village of Ponte, on to the city of the Arch of Trajan (Figure 6). Once in Benevento (Figure 7), after a brief detour to Pietrelcina, the route continues along the Via Traiana, built by the emperor of the same name between 108 and $110 \mathrm{BC}$, which directly links Rome to Brindisi, passing through the municipal territories of Paduli, Buonalbergo and Castelfranco in Miscano before reaching the regional boundary with Puglia. The ancient routes were thus metaphorically retraced, as much as possible using secondary roads with little traffic, scenic and safe to travel, which is a fundamental requirement imposed by the Council of Europe. The need to create a usable tourist product prompted the establishment of a system of itineraries that would allow the construction of circuits of varying length and difficulty, which would lead "slow tourists" to discover the most interesting attractions in the area (Furelos Gaiteiro, 2008).

Among the activities carried out as part of the project were those related to the creation of an information system to publicise the itinerary. As well as guiding the contemporary pilgrim, the signs and posters installed along the route make it possible to identify and appreciate the items of historical interest and the architectural and cultural heritage. Measures to publicise the itinerary include the printing of paper maps and bilingual brochures containing all the information about the municipalities that can be visited, the location of interesting sites, refreshments and accommodation, traditional local products and crafts. A travelling exhibition of archival photographic material represents a way to establish continuity with the devotional practices of the present: images from the past of the religious sites along the itinerary are accompanied by the most significant photos of contemporary pilgrimages and religious events in the places of interest. Last but not least are the measures designed to 
consolidate the itinerary's governance system, which include setting up training courses for public and private operators along the Camino de Santiago and the Via Francigena. The organisation and implementation of short training courses in Galicia, along the route of the Way of St. James, and in Italy, for the Via Francigena, have enabled operators in the Sannio-Beneventano area, particularly young people and women, to learn about the initiatives unfolding in an international context, as well as the results achieved.

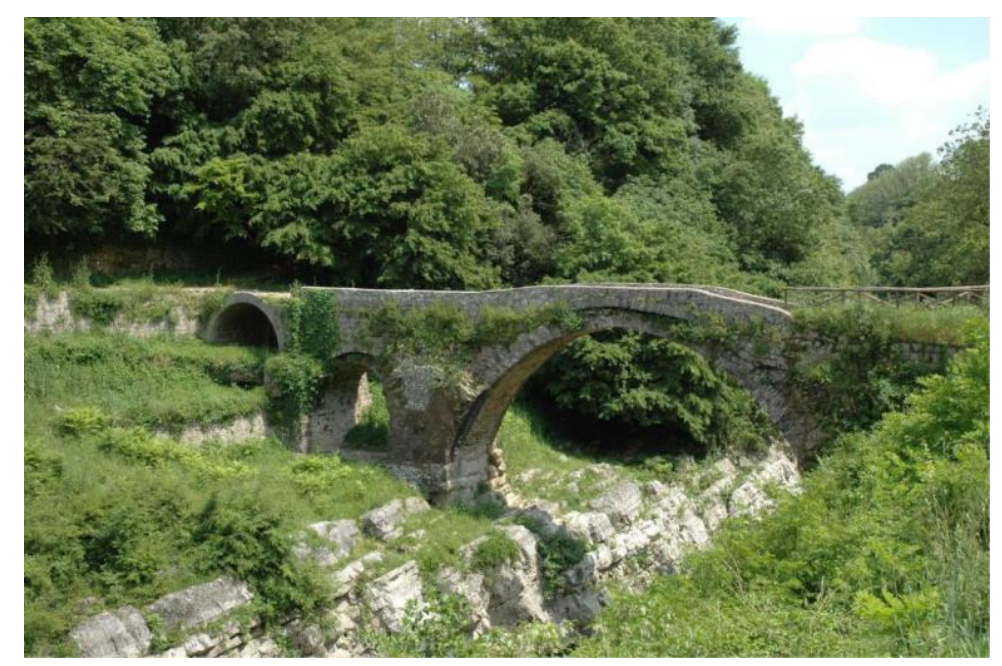

Figure 6. Ponte Fabio Massimo, Faicchio. Source: GAL Titerno.

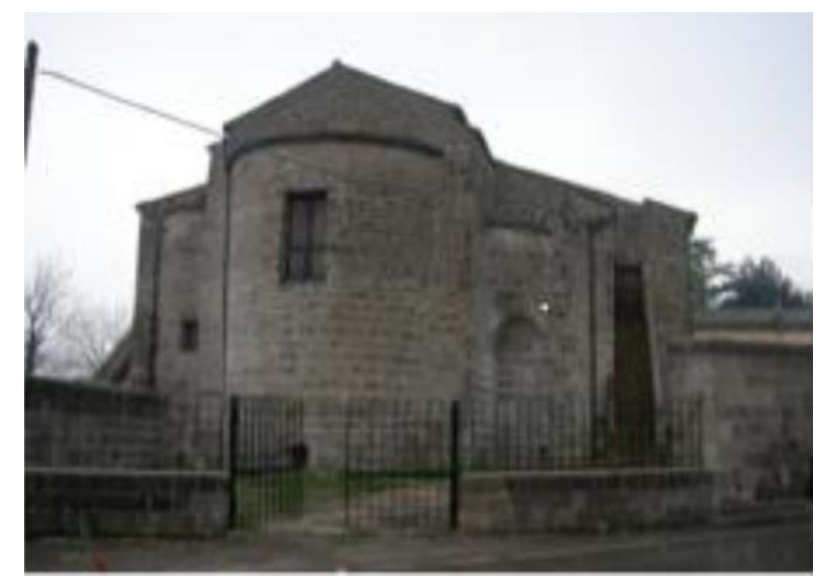

Figure 7. Church and steeple of S. Sofia, Benevento. Source: GAL Titerno.

The managers of the project see the economic exploitation of historical-religious itineraries as a new opportunity to develop the tourist potential of the area, counting on the value of cooperation in bringing together places that are extraordinarily important for tourism and inland areas that are normally excluded from the major international tourism circuits. Experimenting with new measures to promote structures, products and services in rural areas covered by historical and cultural itineraries aims to establish a solid and long-lasting "network of territories". The objective is to increase competitiveness and development opportunities in rural areas and to consolidate the capacity for 
cooperation among the stakeholders and regions of the "Cammini d'Europa" network so as to create a stable, solid and structured partnership.

In spite of the limited evidence of the measures to promote the locations along the Via Francigena implemented by Campania Regional Administration, examination of the current projects reveals some interesting aspects. These include the proliferation of operators who, for various reasons, become part of a "two-headed operation" channelled by the same European steering committee: one bottom-up, which uses the specific planning process as a tool for the physical transformation of the locations, and one top-down, "embedded" in the super-regional context of an ideal intervention. However, the case study highlights the recognition by the community and the institutions of the Via Francigena's role as an itinerary driving measures for the appropriate exploitation of cultural resources and the rebirth of peripheral areas at risk of abandonment and depopulation. Less evident is the impact in terms of increased tourist flows and the birth of new enterprises linked to the passage of contemporary pilgrims (Splendiani et al., 2020).

\section{Conclusions}

Today, the cultural heritage associated with travel experiences on long-distance religious itineraries constitutes evidence of how the promotion of tourism based on an interregional product can activate a virtuous circle of benefits linked to the rebirth of the areas involved.

Due to the rapidly shifting nature of the parties involved in the process of setting up the Route, this study involved limited direct interaction with institutions and local stakeholders. However, it showed how the range of tourism services offered by the Southern Via Francigena is contributing to the increase in the number of users -the number of requests for the "pilgrim's passport" made at the Sanctuary of Santa Maria di Leuca (Puglia), revealed an average annual growth of 65,5\% from 2015 to 2020 -and to the activation of strong synergies between public bodies, cultural associations and the local population, promoting sustainable mobility and raising awareness among visitors and local residents of the need to respect the culture and assets of the area. This objective is already being pursued by a number of local organisations that are able to exploit the Itinerary's potential for real social planning. An example of this is the small town of Cannole (Lecce, Puglia), where individual citizens organised in spontaneous committees have become important points of reference for walkers, providing hospitality and maintaining their stretch of the route while respecting environmental, economic and cultural sustainability.

This study also indicated a significant expansion of the tourism products on offer in the regions, as in the case of the "Cammino dell'anima" in the Benevento area (Campania). This initiative has been able to strengthen the value of the international Francigena itinerary in accordance with the standards of the Council of Europe, as demonstrated by its designation as a "Destination of Sustainable Cultural Tourism 2020", awarded on 30 October 2020 by a jury composed of representatives of Europa Nostra, the European Travel Commission (ETC), NECSTouR and the European Commission.

Despite this, the VFS continues to face numerous difficulties of a technical, organisational and managerial nature (logistics, services, budgeting, reporting, financing, etc.), in addition to marketing and communication issues (lack of ad hoc plans, information management, promotion schemes, etc.), impeding the effective implementation of a successful tourism product. Moreover, there are still operational problems with some segments of the route, not yet "activated" by policy makers, which means that the southern stretch of the Francigena route is not yet fully practicable. Obviously, such difficulties should be investigated in terms of both management and regional political planning, highlighting their assets, weaknesses and elements subject to change.

Whereas in the regions of central Italy, such as Tuscany, the Via Francigena has given rise to a complex, coordinated and monitored tourism product, the undoubtedly great potential of the Via Francigena del Sud has -with the exception of a few special cases- yet to be fulfilled. Elements still lacking from the itinerary include: the necessary signage indicating the variants; the organisation and 
refurbishment of the accommodation structures and other tourism services, both public and private; measures to ensure the usability of the local cultural, historical and architectural heritage; and adequate promotion of the local food-and-wine culture, along with its distinctive traditional products.

The Francigena del Sud is also an interregional cooperation project aimed at exploiting the potential of inland areas crossed by the route. It exemplifies an innovative approach and a new opportunity to manage the tourism potential of the areas involved via cooperation between a variety of entities operating in places that are well-known from a tourism point of view but also in rural areas that are normally excluded from the major national and international tourism circuits. The priority will therefore be to create products and services in the rural areas covered by the route, generating income in various sectors (gastronomy, crafts, transport, accommodation, retail), with the ultimate aim of setting up a solid and lasting "network of areas". Above all, coordination and cooperation will be needed between those who are involved, in various capacities, in its management and promotion. It is important to emphasise creativity, sensitivity, awareness and professionalism in the process of economic exploitation, avoiding speculative operations that are far removed from the pursuit of cultural improvement and the economic objectives of the local community. The fragmentary and changeable nature of local operators means that another common objective should be to promote the principles of participatory management and responsibility for a broad social space in which ideas, practices and experiences can come to life and in which heritage and planning can be co-created. It will also be necessary to guarantee the management of the route and to promote its tourism and cultural products, ensuring that it is continuously active.

In this sense, the Cultural Route translates into an opportunity for the integrated enhancement of the multiple economies involved, as well as acting as a driver of virtuous circles and sustainable mobility, giving new impetus to the economies of the regions involved. This process will allow the concrete "reconnection" of the northern European context (Canterbury), from which it takes its cue, and the Mediterranean basin (all the way to Jerusalem), in the broader framework of reuniting the three peregrinationes maiores, headed towards Rome, Jerusalem and Santiago de Compostela. In this sense, the Via Francigena is not only a bridge between cultures, but also the bearer of a message of cultural exchange and integration.

\section{Author's contribution}

Conceptualization, T.A. and C.V.; methodology, T.A. and C.V.; validation, T.A. and C.V.; formal analysis, T.A. and C.V.; data curation: desk data, T.A. and C.V., field data: T.A.; writing, original draft preparation, T.A. and C.V., review and editing, T.A. and C.V.; supervision, T.A. and C.V.; translation, T.A. and C.V. All authors have read and agreed to the published version of the manuscript.

\section{Acknowledgment}

We would like to thank: Rev. Gianni Leo, Rector of the Shrine of Santa Maria di Leuca; Mr Fabio Stomaci, Councillor of the Municipality of Cannole; Mrs Rosanna Maggio, a volunteer of the "Fabbrica dei Sogni" Association in collaboration with the Parish of Maria Santissima Assunta of the Municipality of Torchiarolo; Mr. Nicola Ciarleglio, Director of GAL Titerno.

\section{References}

Associazione Europea delle Vie Francigene. (2020). Piano strategico 2020-2022. Documento di pianificazione triennale dell'Associazione Europea delle Vie Francigene. Sintesi. Retrieved from: https://www.viefrancigene.org/static/attachments/resources news/Sintesi\%20IT Obiettivi\%20strategici\% 20AEVF.pdf 
Bambi, G., \& Barbari M. (Eds.). (2015). The European pilgrimage routes for promoting sustainable and quality tourism in rural areas. Firenze, Italy: Firenze University Press.

DOI: https://doi.org/10.36253/978-88-6655-812-5

Bate, J. (2011). Public value of the humanities. London, UK: Bloomsbury Academic.

Beltramo, S. (2013). Itinerari culturali e reti di conoscenza: identità e valorizzazione del patrimonio paesaggistico e culturale europeo. Il caso studio del Piemonte. Almatourism. Journal of Tourism, Culture and Territorial Development, 4(7), 13-43. D0I: https://doi.org/10.6092/issn.2036-5195/3908

Berti, E. (2012). Itinerari Culturali del Consiglio d'Europa: tra ricerca di identità e progetto di paesaggio. Firenze, Italy: Firenze University Press.

Berti, E. (2013). Itinerari Culturali del Consiglio d'Europa: nuovi paradigmi per il progetto territoriale e per il paesaggio. Almatourism. Journal of Tourism, Culture and Territorial Development, 4(7), 1-12. DOI: https://doi.org/10.6092/issn.2036-5195/3908

Briedenhann, J., \& Wickens, E. (2004). Tourism routes as a tool for the economic development of rural areas vibrant hope or impossible dream? Tourism Management, 25(1), 71-79. DOI: https://doi.org/10.1016/S0261-5177(03)00063-3

Buratti, N., \& Ferrari, C. (2011). La valorizzazione del patrimonio di prossimità tra fragilità e sviluppo locale. Un approccio multidisciplinare. Milano, Italy: Franco Angeli.

Butler, V. (2012). Local communities, diverse voices. In Localism: Threat or opportunity. Perspectives on the localism act for union and communicty organisers and activists (pp. 23-25). London, UK: TUC. Retrieved from: https://www.tuc.org.uk/tucfiles/354/Localism Guide 2012.pdf

Canova, L. (2012). Itinerari turistici, potenziale strumento di sviluppo locale? In R. Garibaldi (Ed.), Il turismo culturale europeo. Prospettive verso il 2020 (pp. 145-162). Milano, Italy: Franco Angeli.

Dallen, J. T. (2018). Cultural routes: Tourist destinations and tools for development. In D. H. Olsen \& A. Trono (Eds.), Religious pilgrimage routes and trails: Sustainable development and management (pp. 27-36). Boston, MA: CABI International. DOI: https://doi.org/10.1079/9781786390271.0000

Dominioni, S. (2018). Roadmap for the Adriatic-Ionian region. Heritage protection, cultural tourism and transnational cooperation through the Cultural Routes. Strasbourg, France: Council of Europe. Retrieved from: https://www.adriatic-ionian.eu/wp-content/uploads/2019/01/Roadmap.pdf

Fairclough, G. (2011). New heritage frontiers. In Council of Europe (Ed.), Heritage and beyond (pp. 29-42). Strasbourg, France: Council of Europe. Retrieved from: https://rm.coe.int/16806abdea

Furelos Gaiteiro, M. C. (2008). I Cammini d'Europa e la Via Francigena del Sud in Campania e Basilicata. In Associazione Civita (Ed.), Roma-Gerusalemme. Lungo le Vie Francigene del Sud (pp. 151-153). Roma, Italy: Self-Publishing.

Graf, M., \& Popesku, J. (2016). Cultural Routes as innovative tourism products and possibilities of their development. International Journal of Cultural and Digital Tourism, 3(1), 24-44.

Graham, H. (2012). Scaling governmentality. Museums, co-production and re-calibrations of the 'logic of culture', Cultural Studies, 26(4), 565-592. D0I: https://doi.org/10.1080/09502386.2012.679285

González, F., Sánchez, S. M., \& López, T. (2014). Influencia de variables personales en el compromiso organizativo de los empleados del sector hotelero. Revista Galega de Economía, 23(2), 27-46. DOI: https://doi.org/10.15304/rge.23.2.2481

Khovanova-Rubicondo, K. (Ed.). (2011). Impact of European Cultural Routes on SMEs' innovation and competitiveness. European Commission's Competitiveness and Innovation Framework programme (CIP) Retrieved from: https://rm.coe.int/1680706995

Khovanova-Rubicondo, K. M. (2012). Cultural Routes as a source for new kind of tourism development: Evidence from the Council of Europe's Programme. International Journal of Heritage in the Digital Era, 1, 83-88. DOI: https://doi.org/10.1260/2047-4970.1.0.83

Khovanova-Rubicondo, K. M. (2015). Council of Europe Cultural Routes Networks. Governance and sustainable development. In Cultural Routes management: From theory to practice (2015) (pp. 107-114). Strasbourg, France: Council of Europe.

Mansfeld, Y. (2015). Tourism, community and socio-cultural sustainability in Cultural Routes. In Cultural Routes management: From theory to practice (2015) (pp. 73-83). Strasbourg, France: Council of Europe.

Majdoub, W. (2010). Analyzing cultural routes from a multidimensional perspective. Almatourism. Journal of Tourism, Culture and Territorial Development, 1(2), 29-37. DOI: https://doi.org/10.6092/issn.2036-5195/2029

Martínez, F., Novello, S., \& Murias, P. (2009). Análisis de la lealtad de los turistas que visitan la ciudad de Santiago de Compostela. Revista Galega de Economía, 18(2), 5-20. 
Nagy, K. (2012). Heritage tourism, thematic routes and possibilities for innovation. Club of Economics in Miskolc. TMP, 8(1), 46-53.

Ochoa Siguencia, L. O., Gómez-Ullate, M., \& Kamara, A. (Eds.). (2016). Time heritage cultural management and tourism in European Cultural Routes: From theory to practice. House of the Research and Innovation in Education Institute. Retrieved from: https://ec.europa.eu/programmes/erasmus-plus/project-resultcontent/2d749475-4fd5-474b-a90c-58a2296424ea/CMTECR 2016\%20(1).pdf

Rispoli, M. (Ed.). (2001). Prodotti turistici evoluti. Turin, Italy: Giappichelli.

Rizzi, P. (2011). La risposta italiana a Disneyland. In P. Rizzi \& G. Onorato (Ed.), Il turismo culturale e la Via Francigena. La risposta italiana a Disneyland (pp. IX-XVIII). Genova, Italy: Brigati.

Società Geografica Italiana. (2015). Per l'estensione della “Via Francigena nel Sud". Programma degli Itinerari del Consiglio d'Europa. Dossier. Rome, Italy: Società Geografica Italiana.

Retrieved from: https://www.viefrancigenedelsud.it/static/uploads/dossier via francigena nel sud.pdf

Splendiani, S., Forlani, F., Picciotti, A., \& Presenza, A. (2020). Il contributo dei Cammini alla creazione di social value per territori marginali. Il caso della 'Via Francigena'. Proceedings XVII SIM Conference - Il Marketing per una società migliore, Castellanza (Va), LIUC Università Cattaneo, 28-30 ottobre 2020.

Trono, A. (Ed.). (2012). Via Francigena. Cammini di Fede e Turismo Culturale. Galatina, Italy: Congedo.

Trono, A. (2017). Itinerari culturali e turismo spirituale. Sfide ed opportunità della via Francigena Salentina Itinerari culturali e turismo spirituale. In P. Rizzi \& G. Onorato (Eds.), Turismo, cultura e spiritualità. Riflessioni e progetti intorno alla Via Francigena (pp. 27-39). Milano, Italy: Educatt.

Trono, A. (2021). Percorsi e Itinerari Culturali del Versante Adriatico e Ionico del Mediterraneo Orientale. Un "caso" di studio: Regione Puglia. Soleto (Lecce). Panico.

Trono, A., \& Castronuovo, V. (2018). Religious Pilgrimage Routes and trails as driving forces for sustainable local development. In D. H. Olsen \& A. Trono (Eds.), Religious Pilgrimage Routes and Trails (pp. 14-26). Wallingford, UK: CABI.

Trono, A. \& Olsen, D. H. (2018). Pilgrimage trails and routes. Journeys from the present to the future. In D. H. Olsen \& A. Trono (Eds.), Religious Pilgrimage Routes and Trails (pp. 247-254). Wallingford, UK: CABI.

Trono, A., Ruppi, F., Mitrotti, F., \& Cortese, S. (2017). The Via Francigena Salentina as an opportunity for experiential tourism and a territorial enhancement tool. Almatourism. Journal of Tourism, Culture and Territorial Development, 8(6), 20-41. DOI: https://doi.org/10.6092/issn.2036-5195/6330

Vanzo, C. (2021). Itinerarium Burdigalense: Pilgrimage in the 4th century AD. Academia Letters, Article 766. DOI: https://doi.org/10.20935/AL766

Zabbini, E. (2012). Cultural Routes and intangible heritage. Almatourism. Journal of Tourism, Culture and Territorial Development, 3(5), 59-80. DOI: https://doi.org/10.6092/issn.2036-5195/3188

Waligo, V., Clarke, J., \& Hawkins, R. (2015). Embedding stakeholders in sustainable tourism strategies. Annals of Tourism Research, 55, 90-93. D0I: https://doi.org/10.1016/j.annals.2015.09.002 